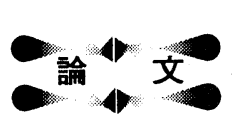

\title{
硬質崖素微小球および多孔質黒鉛粒子の圧縮に伴う 充冝業動と比抵抗
}

\author{
小林和夫，井上隆裕，佐野秀明，内山休男
}

(1995 年 1 月 5 日受理)

\begin{abstract}
Packing Behaviour and Electrical Resistivity of Hard Carbon Microspheres and Porous Graphite Particles under Compression
\end{abstract}

\author{
Kazuo Kobayashi, Takahiro Inoue, Hideaki Sano and Yasuo Uchiyama \\ Department of Materials Science and Engineering, Faculty of Engineering, \\ Nagasaki University, 1-14, Bunkyo-machi, Nagasaki-shi 852, Japan
}

\begin{abstract}
Packing behaviour and electrical resistivity of the powder under compression were investigated on carbon microspheres (CMB) with 1 to $15 \mu \mathrm{m}$ size made from phenol-formaldehyde resin and porous graphite particles (EG) with 15 to $150 \mu \mathrm{m}$ size. Packing density, height of packed particles and electrical resistivity were measured in relation with applied pressure. Shape of the particles was observed by SEM. Value of $n$ of the formula $\rho=a P^{-n}+b$, (where $\rho$ is electrical resistivity, $P$ is an applied pressure, $a$ and $b$ are constant) was also estimated.

$\mathrm{CMB}$ particles with spherical shape had almost closed packing state at the beginning stage of packing and electrical resistivity changed mainly with change of the area of the contact points between CMB particles with elastic deformation under applied pressure. While, EG particles with irregular shape were rearranged and gradually exhibited the preferred orientation by repetition of applying a pressure showing a big elastic deformation. This caused an increase of electrical resistivity along a direction of applied pressure by repetition of loading and unloading. In the case of EG particles change of number of contact points under pressure was thought to cause a change of the electrical resistivity of the powders.
\end{abstract}

KEYWORDS : Carbon Microsphere, Graphite particle, Applied pressure, Packing Behaviour, Electrical resistivity

\section{1.はしがき}

各種の炭素粉末の圧縮下における電気抵抗特性について は, 古くから多くの研究者によって調べられている。赤松 ら1) はカーボンブラックなどの炭素粉末の圧縮下の電気抵 抗を測定し, 加圧が2.9ないし $4.9 \mathrm{MPa}$ 以上のときは、電気 抵抗 $\rho$ と圧力 $P$ との間に,$\rho=a / P+b$ の関係があったこと

長崎大学工学部材料工学科： 7852 長崎市文教町 1-14
を報告している。本田ら2) は炭化過程の異なる各種炭素粉 末の39 196MPa の加圧下の測定を行い, $\rho=a p^{-n}+b$ の 関係式において，ほほ $n=2$ であることを報告した。大谷 ${ }^{31}$ は54.4 217MPa の圧力下における各種合成樹脂炭の電気抵 抗を測定し, 上記関係式中の $\mathrm{n}$ 数は粒子接触点と接触面積 に依存し, 樹脂炭の熱処理温度に伴なう電気抵抗の変化は 結晶子の大きさおよび炭素間の結合様式に依存すると考え た。また, 野田ら4) は各種カーボンブラックの電気抵抗を $900 \mathrm{MPa}$ までの圧力下で測定し, 加圧の初期段階ではカー 
ボンブラック粒子の変形に基づく電気抵抗の減少が, 次の 段階では弾性変形に基づく粒子内の結晶子間の接触の増加 による電気抵抗の減少が結晶子の優先的配向を伴って進む と考察した。また, S. Mrozowskis) は主として仮焼コーク スを用いた実験から, 電気抵抗に及ぼす粒子径, 加圧力, 熱 処理温度，硬度などの関係を詳しく調べている。

これらの研究から, 炭素粉末体の電気抵抗は, 粉末のも つ固有の結晶構造, 結晶子の大きさや集合状態, 粒子の形 状や変形のし易さ, 酸化被膜存在の有無, および粒子の充 填性に影響されることが明らかにされている。これらの研 究において供された炭素粉末は主にコークス, カーボンブ ラック, 樹脂炭である。本研究は, 最近商品化された新しい 形態と特性をもつ硬質炭素微小球および多孔質黒鉛粒子粉 末について, 圧縮に伴う炭素粒子の充填性と比抵抗の関係 を明らかにすることを目的としたものである。

\section{2. 実験方法}

\section{1 試料}

供試料として,フェノール樹脂を原料とした硬質炭素微 小球（日本カーボン（株）製, 商品名: カーボンマイクロ ビーズICB，以下 CMB と略す) および多孔質黒鉛粒子（興 亜石油（株）製, 商品名: エルファイト, A グレード, 以下 EG と略す) を使用した。

試料については，それぞれ，SEM 観察による粒子形態， 学振法に準じたX 線回折による面間隔 $\boldsymbol{d}(002)$, と見掛けの結 晶子の大きさ $L c(002)$, および比重瓶による比重の測定を行 なった。

\section{2 試料粉末体の圧粨に伴う充填挙動と電気抵抗の測定}

試料粉末体の圧縮実験にはFig.1に示す装置を試作した。 試料をCMBについては約 $0.3 \mathrm{~g}$, EGについては約 $0.1 \mathrm{~g}$ を図 中の内径 $10 \mathrm{~mm}$ のアクリル製パイプに入れ，アルミニウム 円柱棒を用いて島津製作所製強度試験機により，0.2 46MPa

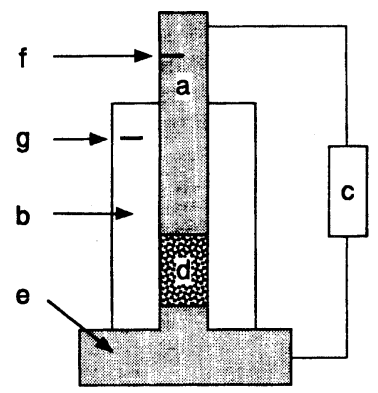

a : Aluminum rod

b : Acrylic pipe with inner diameter of $10 \mathrm{~mm}$

c : Digital multimeter

d : Sample powder

e : Steel base

$f$ : Upper marker

g: Lower marker

Fig.1 Schematic diagram of the apparatus for measurement of electrical resistivity of carbon powders.
の範囲で加圧および除荷を行った。また, 読み取り顕微鏡 によりアルミニウム円柱棒およびアクリルパイプにつけた マーカー間隔を測定することにより, 加圧下の試料充填高 さを求め, さらに試料重量と容積から加圧下のかさ密度を 計算した。また, $0.2 \mathrm{MPa}$ 加圧下での試料充填高さ $L_{0}$ を基 準にとり, 加圧に伴う試料充填高さの変化量 $\Delta L / L_{0}$ を測定 した。ここで, $\Delta L=L_{0}-L$ であり,$L$ は各加圧下における 試料高さである。粉体を圧縮する場合，最初の試料高さを 大きくすると試料と器壁との摩擦による圧力分布の不均質, 応力が粒子間の接触部を介して伝わっていくときの減衰に よる応力分布の不均質が生ずる。この応力分布の不均質を 低減するため, 試料量は少な目にし, 自由堆積状態で試料 高さが $3 \mathrm{~cm}$ 程度になるようにした。また，加圧，除荷 $(0.2 \mathrm{MPa} \Leftrightarrow 46 \mathrm{MPa})$ は繰り返し行い，その影響も検討した。 加圧下の粉末体の電気抵抗は, デジタルマルチメータに よりアルミニウム円柱棒と下部のスチール製支持台間の電 気抵抗を測定した。比抵抗值は, 電気抵抗值 $\times$ (面積/圧 粉体の高さ）より計算した。また，EG粒子においては，粒 子形状が不規則であり，圧縮状態においては電気抵抗値に 方向性の相違が現われることが予測されたため，Fig.2に示 す装置を作成し, 加圧方向に垂直方向の電気抵抗值も測定 した。この場合, 装置の強度の関係から, 最大加圧力は $30.8 \mathrm{MPa}$ とした。

また, 最大加圧 46MPa 下における圧縮時の粒子状態を観 察するために, 試料粉末中に約 $0.1 \mathrm{~g}$ の試料埋め込み用樹脂 を添加し, 加圧した後, $46 \mathrm{MPa}$ の最大加圧状態で樹脂を硬 化させることにより圧縮状態の粉末体を固定させ，除荷後， 試料を破断してその研磨面をSEMにより観察した。

\section{3. 結果と考察}

\section{1 試料粒子の形態, 比重およびX線回折データ}

Fig.3 に供試料のSEM 写真を示す。CMB 粒子は真球に 近い球形を呈し, 約 $1 \sim 15 \mu \mathrm{m}$ の粒径分布をしており, 粒子

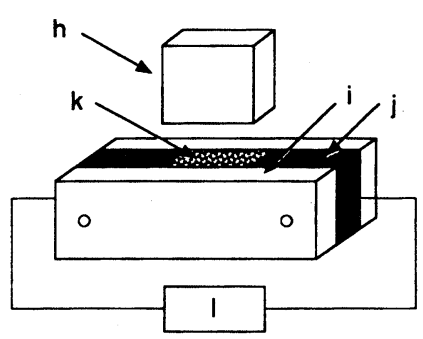

h : Acrylic rod i : Acrylic plate j : Metallic plate k : Sample powder

I : Digital multimeter

Fig.2 Schematic diagram of the apparatus for measurement of electrical resistivity along a normal direction to applied pressure. 


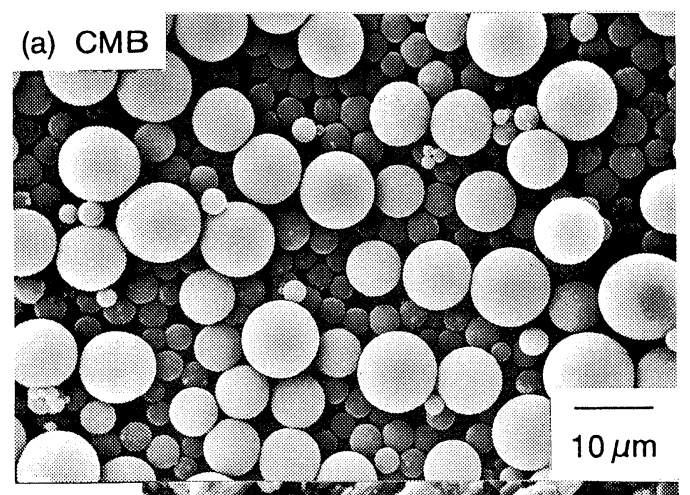

Table 1 Density, $d_{(002)}$ and $L c{ }_{(002)}$ of carbon powders used.

\begin{tabular}{lccc}
\hline & density $\left(\mathrm{g} / \mathrm{cm}^{3}\right)$ & $d(002)(\AA)$ & $L c(002)(\AA)$ \\
\hline \hline CMB & 1.35 & 3.53 & 18 \\
\hline EG & 1.66 & 3.39 & 281 \\
\hline
\end{tabular}
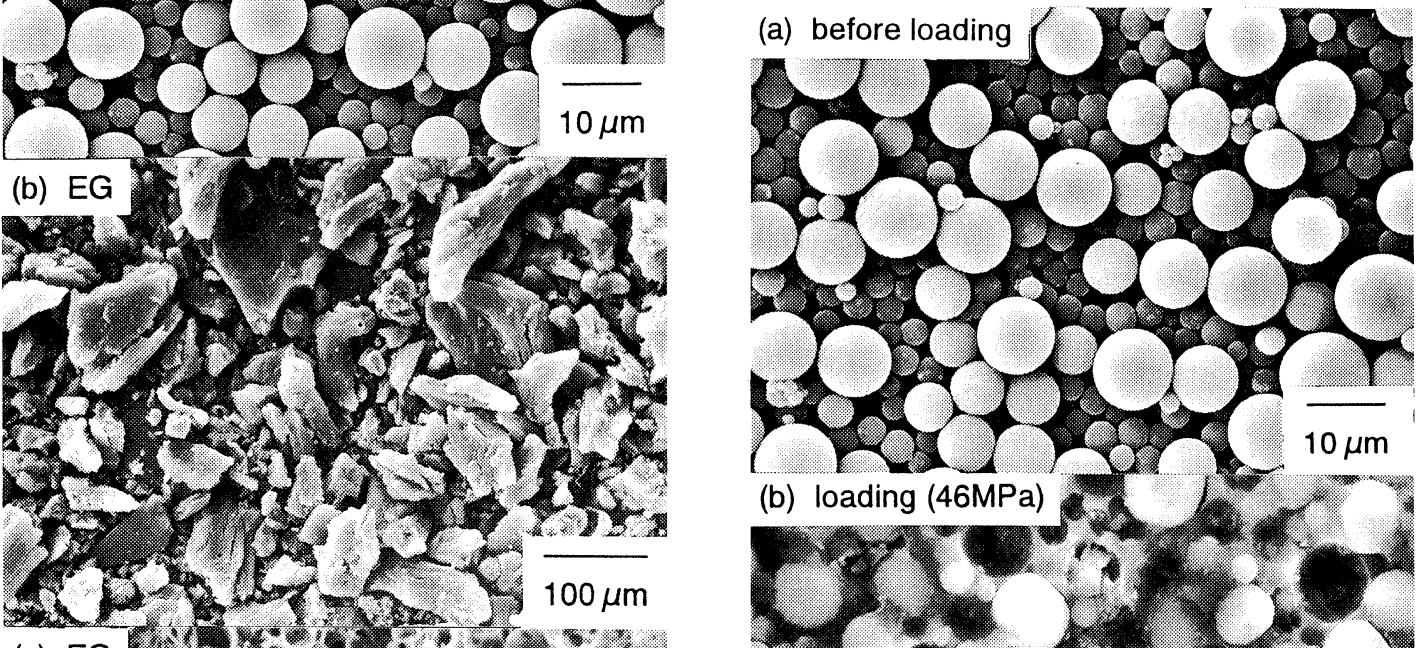

(c) EG
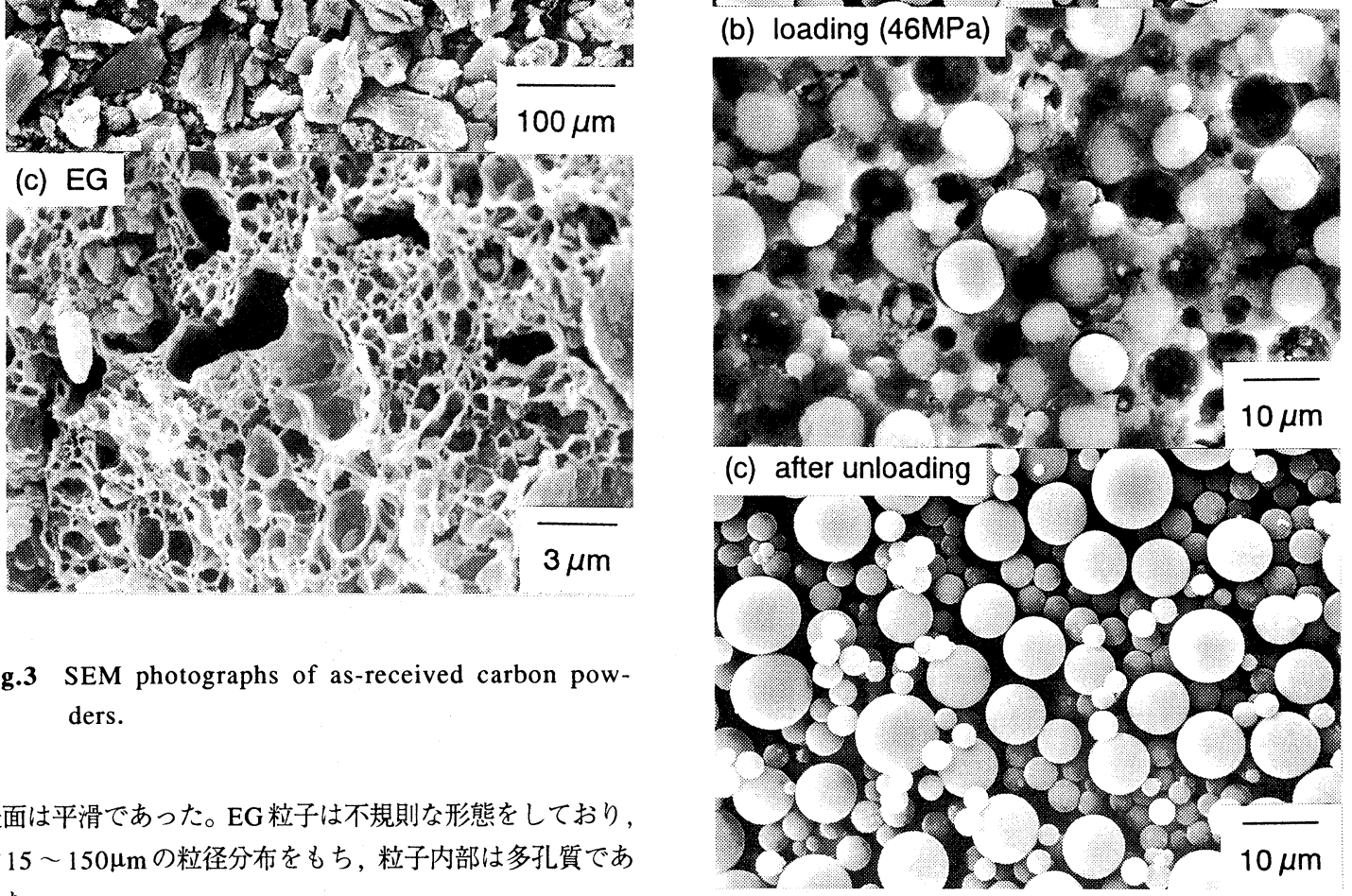

表面は平滑であった。EG 粒子は不規則な形態をしており,

約 $15 \sim 150 \mu \mathrm{m}$ の粒径分布をもち, 粒子内部は多孔質であ った。

Table 1 にX 線回折より求めた炭素の層面間隔 $d_{(002)}$ と 見かけの結晶子の大きさ, $L c(002)$, および比重瓶により求 めた比重を示す。CMB 粒子の $d(002)$ は $3.53 \AA ⿻, L c{ }_{(002)}$ は $18 \AA$, EG 粒子の $d_{(002)}$ は $3.39 \AA ⿻ 上 丨(002)$ は $281 \AA$ であった。

\section{2 加圧前後の粒子形態の変化}

Fig.4にCMB 粒子, Fig.5にEG 粒子の加圧前, 加圧下, および除荷後の粒子形態を示す。加圧下のSEM 写真におい

Fig.4 SEM photographs of morphology of CMB before, under and after loading.

て，粒子周辺のマトリックス部分に存在する物質は固定の ために添加した埋め込み用樹脂である。いずれも加圧前と 除荷後の粒子形態に変化は認められなく, 加圧による粒子 の破壊は生じなかったものと思われる。しかし，加圧状態 
(a) before loading

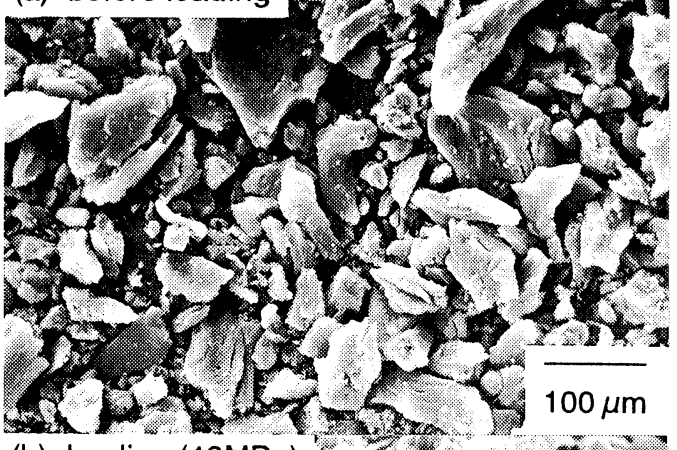

(b) loading (46MPa)

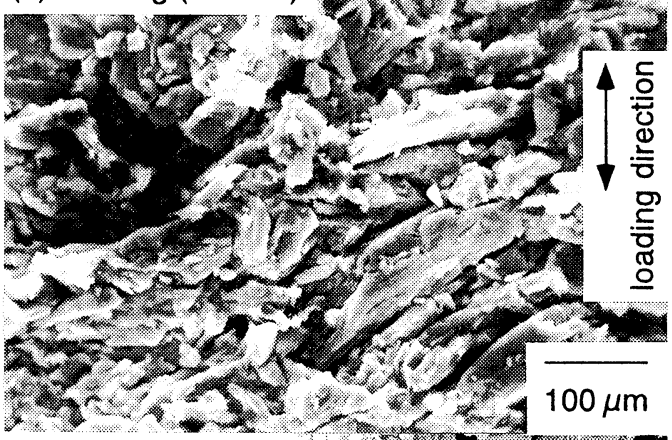

(c) after unloading

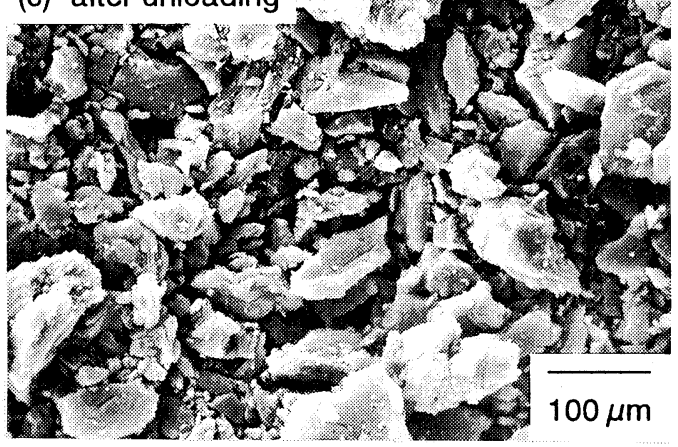

Fig.5 SEM photographs of morphology of EG before, under and after loading.

下においては粒子の変形が, $\mathrm{CMB}$ 粒子において若干, EG 粒子においては顕著に認められた。すなわち, CMB 粒子に おいては，ややいびつになった球状粒子の存在が観察され， EG 粒子においては, 粒子が原形より扁平な形態になってお り, 粒子の長軸が加圧方向に垂直な方向に配向する傾向が 認められた。これら圧縮時に変形を呈した粒子は，除荷す ることによりほほ原形が回復した。しかし，EG粒子粉末体 においては, 最大加圧時に生じた粒子の配向組織は, くり かえし荷重における最小加圧状態下ではその傾向が残るこ とが予測された。

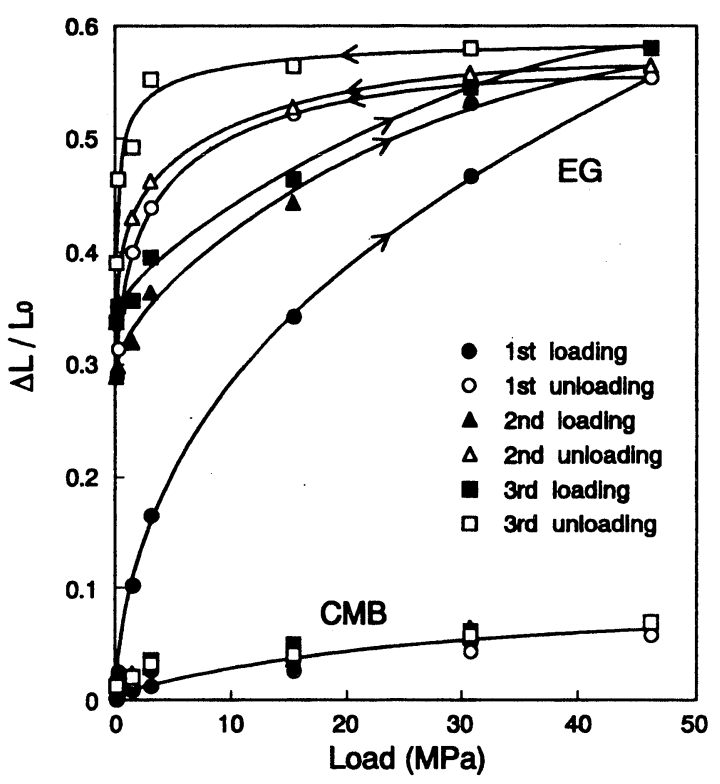

Fig.6 Change of height $\left(\Delta L / L_{0}\right)$ of CMB and EG under loading and unloading.

\section{3 加圧に伴う試料粉末体の高さ変化}

加圧に伴う $\Delta L / L_{0}$ の值の変化を Fig.6に示す。

$\mathrm{CMB}$ 粒子の場合, 加圧力の増加に伴い, 試料高さの変化 率はほほ直線的に増加した。また, 試料高さの変化率は小 さく $46 \mathrm{MPa}$ 加圧時でその変化率は 0.06 であった。また, 加 圧, 除荷の繰り返しによる試料高さの変化率をみても, 一 回目の加圧とほほ同一の軌跡を示した。一回目の加圧と3 回目の除荷における初期加圧 $0.2 \mathrm{MPa}$ 時の試料高さの変化 率の差は 0.01 と極めて小さかった。このことは, CMB 粒子 はほほ真球に近い球形をしており，最初の充填でほほ最密 充填に近い充填状態になり，その後の加圧では主として粒 子の弾性変形により粉末体の変形が進んだと推定できる。 しかし，CMB 粒子は硬質であるため，加圧による粒子の変 形量は少なく，したがって $\Delta L / L_{0}$ の小さい值が得られたこ とがわかる。

$\mathrm{EG}$ 粒子の場合の加圧力と試料高さの変化率の関係をみ ると, $\mathrm{CMB}$ 粒子と異なり, 初期加圧においては急激な $\Delta L / L_{0}$ の増加を示し, その後加圧力の増加に伴い緩やかな変 化となった。この傾向は繰り返し回数か増すにつれて顕著

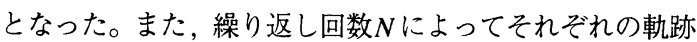
は異なり, $N$ 回目の除荷と $(N+1)$ 回目の加圧では, $N$ 回 目の除荷の方が試料高さの変化率が大きいことがわかった (ただし $N=1,2$ である)。EG粒子は不規則な形状をもち， かつ多孔質である。最初の充填では粒子配列は乱雑であり, かなりの空隙部分が存在していたと考えられる。加圧と除 


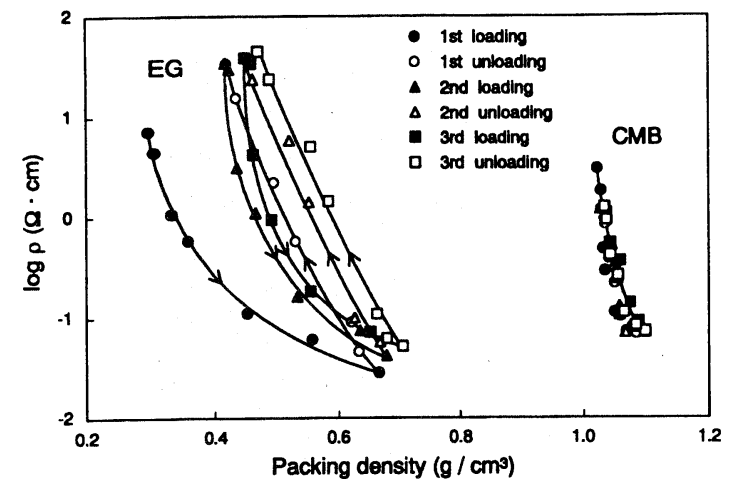

Fig.7 Relation between packing density and electrical resistivity $(\rho)$ of $C M B$ and EG under loading and unloading.

荷の繰り返しにより粒子の移動に伴う再配列と緻密化が進 むため, 繰り返しによる軌跡の差が生じたと判断される。 また, EG粒子は多孔質黒鉛体であり，大きな弾性変形をす るため, 大きな $\Delta L / L_{0}$ を示したと考えられる。

\section{4 充填密度と比抵抗の関係}

加圧と除荷に伴う充填密度と比抵抗の関係を Fig.7に示 す。加圧過程においては充填密度の増加とともに比抵抗は 減少し, 除荷過程においては充填密度の減少とともに比抵 抗は増大した。また, 加圧力と比抵抗の関係をCMBについ てはFig.8に, EGについてはFig.9に示す。

$\mathrm{CMB}$ 粒子の場合, 充填密度と比抵抗の関係は繰り返し回 数によらず，いずれもほほ同一の軌跡を示した。初期の $0.2 \mathrm{MPa}$ の加圧から最大 $46 \mathrm{MPa}$ の加圧まで, 充填密度は 1.02 から $1.08\left(\mathrm{~g} / \mathrm{cm}^{3}\right)$ 一増加し, その変化量は 0.06 $\left(\mathrm{g} / \mathrm{cm}^{3}\right)$ と微小であった。

また, 初期の0.2MPa から最大 $46 \mathrm{MPa}$ の加圧まで, 比抵 抗は3.04から $0.07 \Omega \cdot \mathrm{cm}$ 个減少した。同じ $0.2 \mathrm{MPa}$ の加圧 時でも一回目加圧開始時と除荷終了時の比抵抗值を比較す ると, 除荷終了時の方が低い比抵抗值を示した。これは加 圧により粒子配列の緻密化が進行し，粒度分布も実際には あるので加圧開始時に比べると除荷終了時では粒子同士の 接触点の数が増加したために比抵抗值が減少したと考えら れる。しかし，CMB 粒子は高硬度であり，加圧初期にすで に，ある程度最密充填に近い配列をとるために，その後は 加圧および除荷の繰り返しによる粒子の移動が少なく，そ の結果, 充填密度の小さい変化領域で比抵抗は変化し, 繰 り返しにおいてほほ同一の軌跡を示したと推定される。

$\mathrm{CMB}$ 粒子の比重瓶法による密度測定結果は， 1.35 $\left(\mathrm{g} / \mathrm{cm}^{3}\right)$ であった。CMB を均一剛体球であると仮定すると 最密充填での充填密度は $1.00\left(\mathrm{~g} / \mathrm{cm}^{3}\right)$ となる。実験により

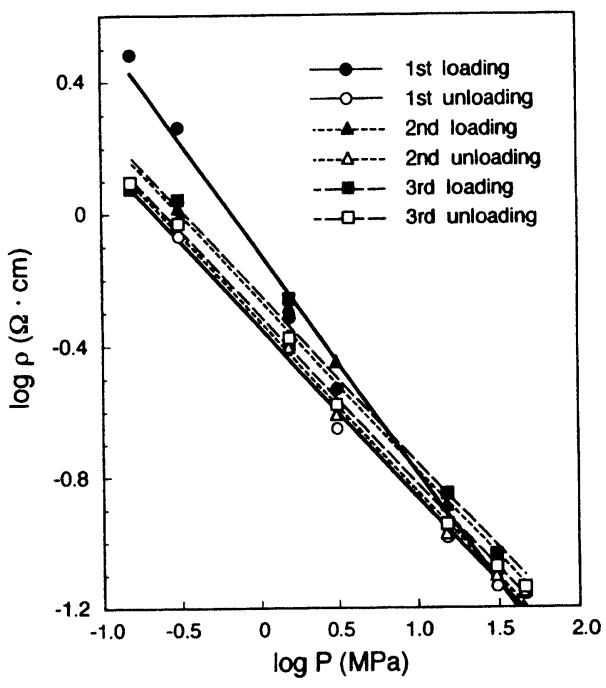

Fig.8 Relation between load and electrical resistivity $(\rho)$ under loading and unloading of CMB.

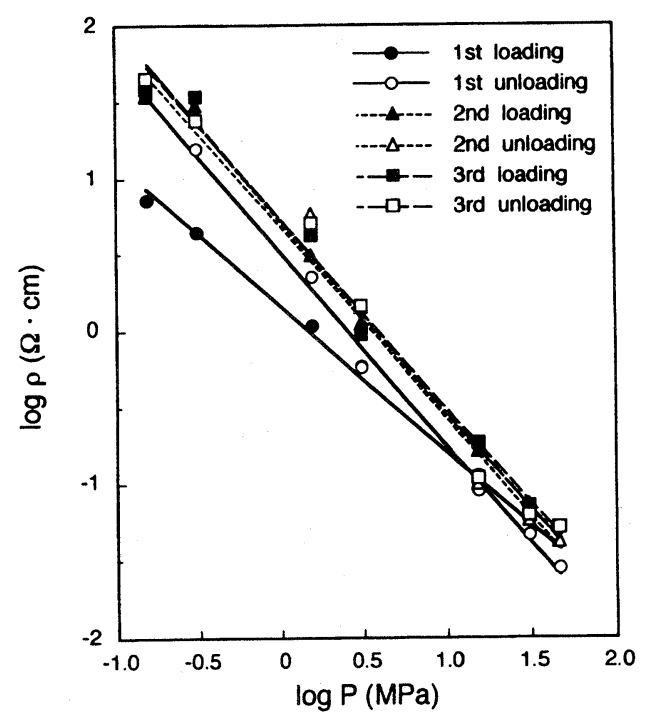

Fig.9 Relation between load and electrical resistivity $(\rho)$ under loading and unloading of EG.

求められた充填密度は初期の $0.2 \mathrm{MPa}$ 加压時ですでに 1.00 $\left(\mathrm{g} / \mathrm{cm}^{3}\right)$ を越えており，CMBの粒度分布を考慮しても，初 期充填でCMB 粒子はほほ最密充填に近い配列をしたこと が裏付けられる。

EG 粒子の場合, 初期の 0.2 から 46MPa の加圧まで, 充填 密度は 0.30 から $0.67\left(\mathrm{~g} / \mathrm{cm}^{3}\right)$ 一増加し, その変化量は0.37 $\left(\mathrm{g} / \mathrm{cm}^{3}\right)$ とCMB 粒子に比較して大きな值を示した。比重瓶 
によるEG 粒子の密度測定結果は $1.66\left(\mathrm{~g} / \mathrm{cm}^{3}\right)$ であり，も LEG 粒子を均一剛体球と仮定すると, 最密充填での充填密 度は $1.23\left(\mathrm{~g} / \mathrm{cm}^{3}\right)$ であり, 46MPa 加圧時の充填密度 0.67 $\left(\mathrm{g} / \mathrm{cm}^{3}\right)$ はこの值と比較して小さい。これは EG 粒子が不 規則形状多孔質であるため, 加圧時における充填密度が低 い值を示したと考えられる。

比抵抗は，0.2 から $46 \mathrm{MPa}$ の加圧により，7.22 から0.03 $\Omega \cdot \mathrm{cm}$ 一減少した。また, 加圧開始時と除荷終了時の $0.2 \mathrm{MPa}$ 加圧下での比抵抗を比較すると, 除荷終了時の方が 高い比抵抗値を示した。さらに, 加圧過程と除荷過程では 軌跡が異なった。また，繰り返し回数によっても軌跡が異 なり, 加圧開始時あるいは最大加圧時を比較すると, 加圧. 除荷の繰り返しが増すにつれて充填密度は増加し, 同じ加 圧下では徐々に高い比抵抗を示すことが認められた。

ここでEG粒子においては, 充填密度は繰り返しにより増 加しているにもかかわらず，比抵抗が増加した原因は粒子 の配向によるものと考え，Fig.2に示す装置により，0.2か ら $30.8 \mathrm{MPa}$ の加圧範囲の加圧方向に対して垂直な方向の比 抵抗を測定した。その結果を Fig.10に示す。加圧, 除荷の 繰り返しにより $0.2 \mathrm{MPa}$ の加圧開始時の比抵抗は徐々に減 少することが認められた。

Fig.5のSEM写真からもわかるように, 加圧状態では, EG 粒子は変形し, 粒子の長軸が加圧方向に対して垂直に配 向する傾向が認められる。除荷しても粒子の配向性は残る ため,また，繰り返しにより粒子の配向性は増加するため，

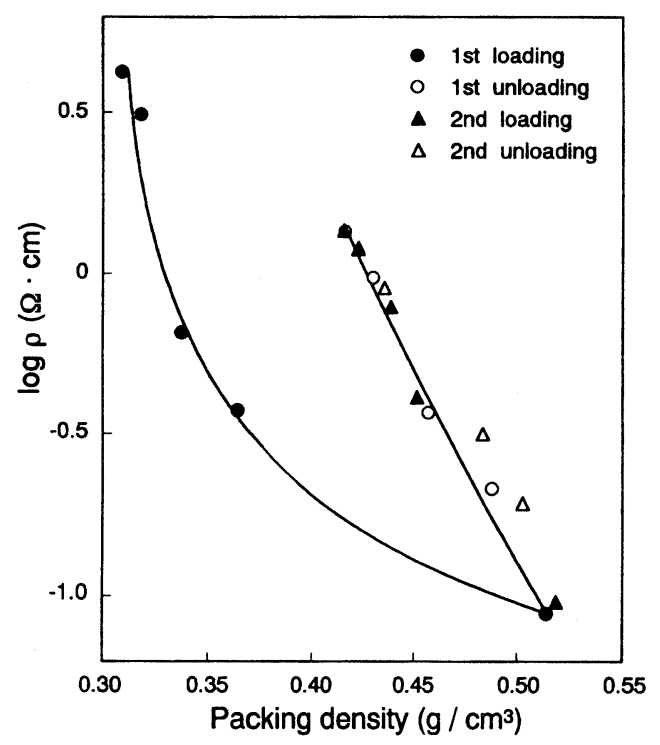

Fig.10 Relation between packing density and electrical resistivity $(\rho)$ of EG along a normal direction to applied pressure.
黒鉛の $\mathrm{c}$ 面方向が多くそろった水平方向の比抵抗が徐々に 隇少し, 加圧方向の比抵抗は徐々に増大したことがわかる。

炭素粉末の比抵抗 $\rho$ と加圧力 $P$ との関係については, $\rho=$ $a P-\mathrm{n}+b$ の関係式 $(a, b$ は炭素の種類によって決まる定数 $)$ におけるnの值で古くから多〈議論されてきている1)-5)。上 式はH. Holm ${ }^{6)}$ の塑性変形する金属粉末の接触点と比抵抗 の理論から導かれたものであり, 粒子に塑性変形がなく, 圧力の増加により接触面積は増加せず, 接触点の数のみ増 加する場合は $n=1$ であり, 塑性変形があり, 圧力の增加に より接触点の数は増加せず, 接触面積のみ増加する場合は $n=0.5$ になるどされている。しかし，実際の実験において はさまざまの値をとることも報告されている。

例えば, 大谷3) は, $54.4 \sim 217 \mathrm{MPa}$ の圧力範囲において 各種樹脂炭の実験を行い, $n=0.66 \sim 1.07$ を得ている。そ して,$n$ 值が 1 および 0.5 の両群に別れず，その中間值であ ったことは, 加圧による接触点の増加と接触面積の増加が 同時に生じたためであると考察している。また, 野田ら4) は，サーマルブラックなどを用いた超高圧下での実験から， 加圧初期の段階では接触点の増加がおこり, 第2段階では 粒子の変形に伴う接触面積の増加がおこり, 第3段階では 結晶子の優先的配向と弾性変形による結晶子の接触点の増 加により, $n$ が0.23に減少すると述べている。

Fig.8におけるCMB 粒子の加圧, 除荷の絽り返しにおけ る加圧力の対数と比抵抗の対数の関係における直線の勾配 より求めた $n$ 值をTable 2 に示す。一回目の加圧におけるn 值は0.67であったが, その後の除荷および繰り返しにおい てはいずれも $0.5 に$ に近い值であった。このことは, $\mathrm{CMB}$ 粒 子は完全球形であり, 表面は平滑であるので, 一回目の加 圧では粒子の移動による接触点の増加が加わるが, すぐに 最密充填に近い状態となり, その後の加圧, 除荷の繰り返 しによる粒子の移動は極めて少なく, 加圧下のSEM 写真か らもわかるように主に球形粒子の弾性変形による接触面積 の変化により比抵抗が変化したことを示している。

Fig.9におけるEG 粒子の加圧, 除荷の繰り返しにおける 加圧力の対数と比抵抗の対数の関係から求めた $n$ 值を Table 3 に示す。一回目の加圧過程では, $n=0.95$ であり, その後 は除荷, 加圧の繰り返しにおいては, 変化がほとんどなく, $n$ 值は1.23〜1.29を示した。EG粒子はFig.3に示したよう

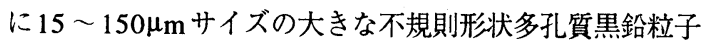

Table $2 n$ value of CMB.

\begin{tabular}{ccc}
\hline & loading & unloading \\
\hline \hline 1st & 0.67 & 0.52 \\
\hline 2nd & 0.52 & 0.52 \\
\hline 3rd & 0.51 & 0.51 \\
\hline
\end{tabular}


Table $3 n$ value of EG.

\begin{tabular}{ccc}
\hline & loading & unloading \\
\hline \hline 1st & 0.95 & 1.27 \\
\hline 2nd & 1.23 & 1.29 \\
\hline 3rd & 1.24 & 1.27 \\
\hline
\end{tabular}

である。また，SEM観察および加圧方向とそれに垂直な方 向の比抵抗の測定から，EG 粒子は加圧により再配列が進行 し，配向しやすいことが判っている。さらに，SEM観察に より，加圧下で大きく弾性変形することが認められている。 多孔質黒鉛組織のため容易に変形するが, 不規則形状かつ 大粒子のため, かつ多孔質のため, 変形による接触面積の 増大よりも，粒子相互間の接触点の数の増大が粒子内部の 接触点の増加とともに, 比抵抗の変化に大きく寄与し, $n=$ 1 前後の值を示したものと思われる。

\section{4. まとめ}

フェノール樹脂を原料とした硬質炭素微小球（日本カー ボン(株製, 商品名：カーボンマイクロビーズICB, CMB と 略）および多孔質黒鉛粒子（興覀石油侏製，商品名：エル ファイト, EG と略）の圧縮に伴う充填挙動と比抵抗を調べ た。また, $\rho=a P^{-n}+b$ ( $\rho$ : 比抵抗, $P$ : 加圧力, $a$ およ びbは炭素の種類によってきまる定数）の関係式における $n$ 値を検討した。

$\mathrm{CMB}$ 粒子は $1 \sim 15 \mu \mathrm{m}$ の粒径でほほ真球に近い球形をし ており, 加圧, 除荷の繰り返しにおける加圧力と粒子充填

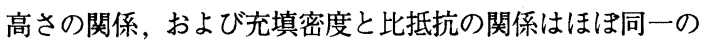
軌跡を示した。また, CMB 粒子は加圧下で弾性変形してい ることが認められた。 $n$ の值はほほ 0.5 と一定しており,こ れらのことから, CMB 粒子は, 最初の充填でほぼ最密充填
に近い状態となり, その後の加圧, 除荷では, 球体粒子の弾 性変形による接触面積の増減が比抵抗の変化に寄与してい ることが推定された。

EG 粒子は, $15 \sim 150 \mu \mathrm{m}$ の CMB に比較して大きな粒径 をもち, 黒鉛質で形状は不規則であり, 粒子内部は多孔質 である。加圧により粒子は扁平な形となり，粒子の長軸が 加圧方向に垂直な方向に配向する傾向が認められた。加圧 下の再配列による配向化のため, EG 粒子充填体において は, 同じ加圧力下での充填密度は絽り返しにより増加する にもかかわらず加圧方向の比抵抗は増加した。EG粒子は, 大きな弾性変形を示すが, 不規則形状で多孔質, かつ軟質 な黒鉛質であるため, 加圧, 除荷下の変形による接触面積 の変化よりも粒子相互間および粒子内部の接触点の数の変 化が比抵抗の変化に寄与するものと考えられた。

謝辞：実験試料を提供して頂いた日本カーボン(侏掠よび 興严石油(侏の関係の方々に厚くお礼申し上げる。

\section{文献}

1）赤松秀雄, 井口洋夫, 日本化学雑誌 70（1949）185189.

2) 本田英昌, 大内公耳, 豊田貞治, 日本化学雑誌 76 (1955) 364-368.

3）大谷杉郎, 工業化学雑誌 60 (1957) 407-410.

4) T. Noda, H. Kato, T. Takasu, A. Okura and M. Inagaki, Bull. of the Chemical Society of Japan 39 (1966) 829-833.

5) S. Mrozowski, Proc. Third Biennial Carbon Conf., Pergamon Press (1959) 495-508.

6) R. Holm, Wiss. Veroff. Siemens-Konzern 7 (1929) 217-271. 